DIC

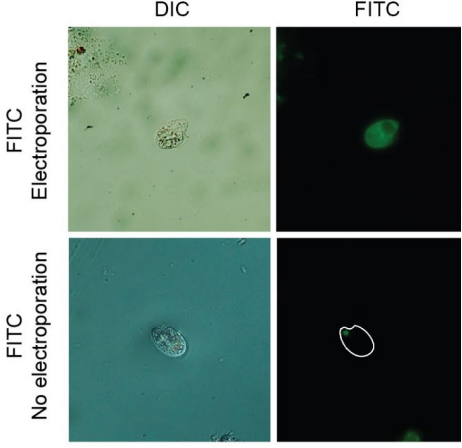

VERSION 3

MAY 24, 2019

\section{open $\boldsymbol{\sigma}$ Access}

DOI:

dx.doi.org/10.17504/protocol s.io. $3 \mathrm{cmgiu} 6$

\section{External link:}

https://doi.org/10.1038/s415 92-020-0796-x

Protocol Citation: Nick Irwin, Elisabeth Hehenberger, Liz Cooney, Yoshihisa Hirakawa, Patrick Keeling 2019.

Electroporation transformation of FIC-dextran into Oxyrrhis marina - an early branching dinoflagellate.. protocols.io https://dx.doi.org/10.17504/p rotocols.io. $3 \mathrm{cmgiu} 6$

\section{(3) Electroporation transformation of FITC-dextran into Oxyrrhis marina - an early branching dinoflagellate. V.3}

[] Nature Methods

Nick Irwin ${ }^{1}$, Elisabeth Hehenberger ${ }^{1}$, Liz Cooney ${ }^{1}$, Yoshihisa Hirakawa ${ }^{2}$, Patrick Keeling ${ }^{1}$

${ }^{1}$ University of British Columbia; ${ }^{2}$ University of Tsukuba

Protist Research to Optimize Tools in Genetics (PROT-G)

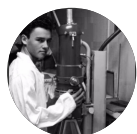

Nick Irwin

University of British Columbia

\section{ABSTRACT}

\section{INTRODUCTION}

Here we describe a protocol for transforming Oxyrrhis marina with FITC-labelled dextran (a DNA analog) by electroporation.

This protocol is reproducible, and results in a transformation efficiency of around $1 \%$.

We have confirmed the viability of transformed cells by allowing them to recover in the dark (and thus maintain fluorescence intensity) and then by observing fluorescent cells swimming normally, days after transformation (see the video here).

\section{NOTE ON AUTOFLUORESCENCE}

Although Oxyrrhis is a non-photosynthetic dinoflagellate and therefore lacks plastid autofluorescence, we have observed a small amount of green autofluorescence that is typically isolated in the anterior of the cell (See top panel of Figure 1).

The autofluorescence was observed in wildtype cells, cells electroporated without FITC-dextran, and cells that were incubated with FITC-dextran but not electroporated. The autofluorescence was observed in cultures with both Dunaliella tertiolecta or heat-killed $E$. coli. The brightness and frequency of the autofluorescence also seemed to be dependent on culture conditions. Not all cells had the autofluorescence. 
MANUSCRIPT CITATION:

Faktorová D, Nisbet RER, Robledo JAF, Casacuberta E, Sudek $L$, Allen $A E$, Ares $M$, Aresté C, Balestreri C, Barbrook AC, Beardslee $P$, Bender S, Booth DS, Bouget F, Bowler C, Breglia SA, Brownlee $C$, Burger $G$, Cerutti $\mathrm{H}$, Cesaroni $\mathrm{R}$, Chiurillo MA, Clemente T, Coles DB, Collier JL, Cooney EC, Coyne K, Docampo R, Dupont $\mathrm{CL}$, Edgcomb V, Einarsson E, Elustondo PA, Federici $F$, Freire-Beneitez $\mathrm{V}$, Freyria NJ, Fukuda K, García PA, Girguis PR, Gomaa F, Gornik SG, Guo J, Hampl V, Hanawa $Y$, Haro-Contreras $E R$, Hehenberger $E$, Highfield A, Hirakawa $Y$, Hopes A, Howe CJ, Hu I, Ibañez J, Irwin NAT, Ishii $Y$, Janowicz NE, Jones AC, Kachale A, Fujimura-Kamada K, Kaur B, Kaye JZ, Kazana E, Keeling PJ, King N, Klobutcher LA, Lander N, Lassadi I, Li Z, Lin S, Lozano J, Luan F, Maruyama S, Matute T, Miceli C, Minagawa J, Moosburner M, Najle SR, Nanjappa D, Nimmo IC, Noble L, Vanclová AMGN, Nowacki M, Nuñez I, Pain A, Piersanti A, Pucciarelli $S$, Pyrih J, Rest JS, Rius M, Robertson D, Ruaud A, RuizTrillo I, Sigg MA, Silver PA, Slamovits $\mathrm{CH}$, Smith $\mathrm{G}$, Sprecher BN, Stern R, Swart EC, Tsaousis AD, Tsypin $L$, Turkewitz A, Turnšek J, Valach $M$, Vergé $V$, Dassow Pv, Haar Tvd, Waller RF, Wang $L$, Wen $X$, Wheeler $G$, Woods A, Zhang $H$, Mock $T$, Worden AZ, Lukeš J, Genetic tool development in marine protists: emerging model organisms for experimental cell biology. Nature Methods 17(5). doi: 10.1038/s41592020-0796-X

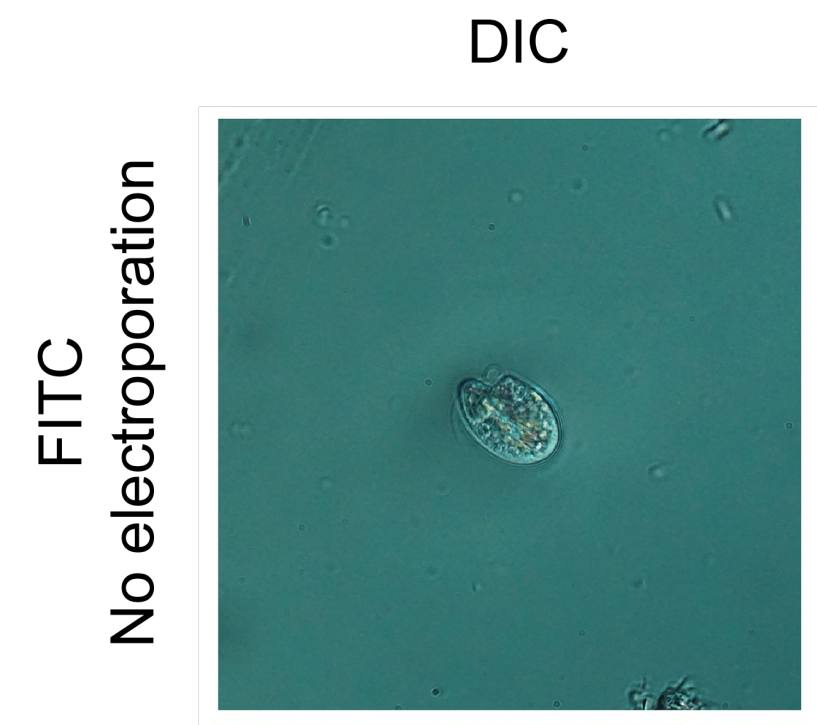

FITC
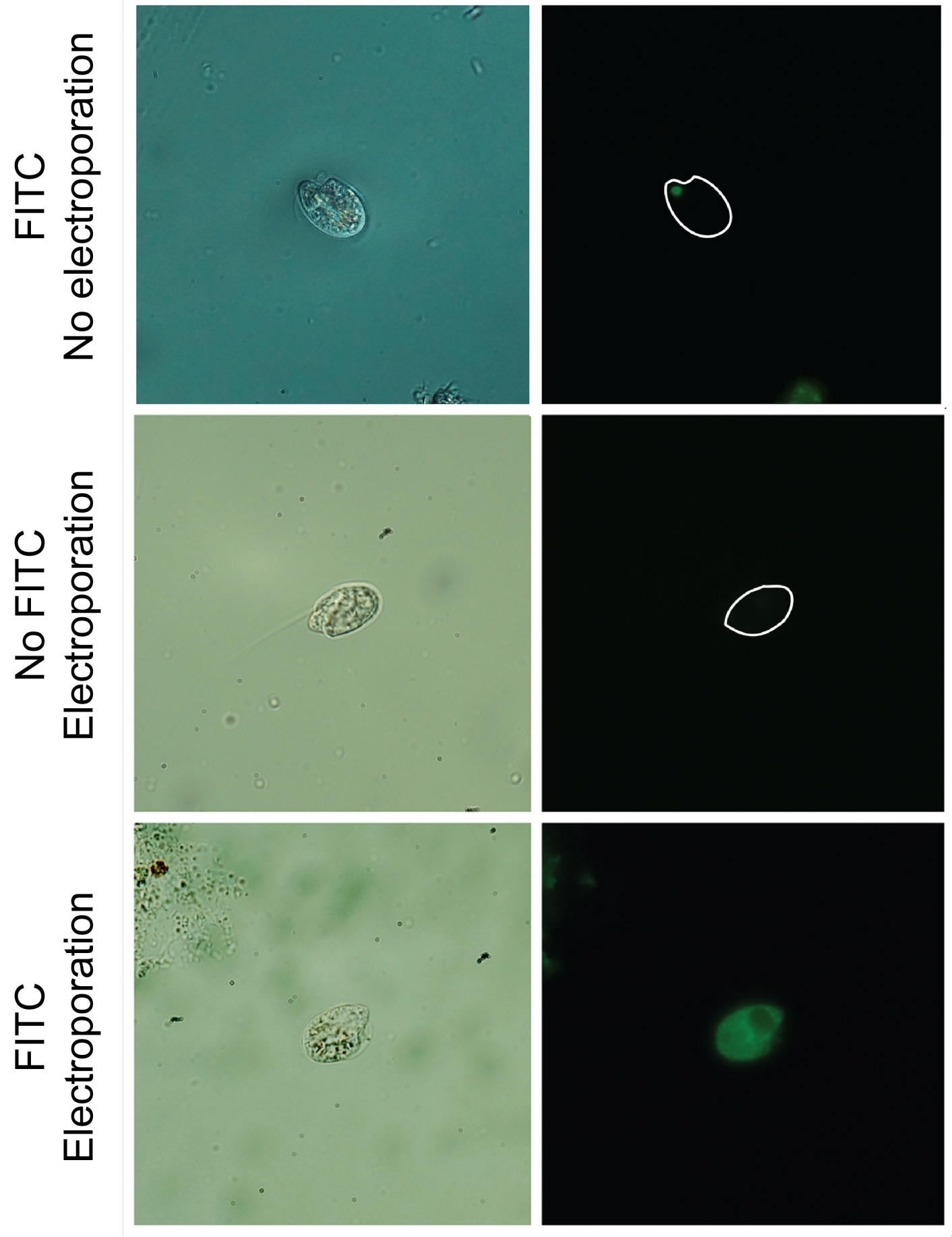

Figure 1. Electroporation of Oxyrrhis marina with FITC-dextran. Top pannel: $O$. marina incubated with FITC-dextran but not electroporated. Middle pannel: $O$. marina electroporated without FITC-dextran. Bottom pannel: O. marina electroporated with FITC-dextran. Cells with (ex. top pannel) and without (ex. middle pannel) were observed in both negative controls. 
License: This is an open access protocol distributed under the terms of the Creative Commons Attribution License, which permits unrestricted use, distribution, and reproduction in any medium, provided the original author and source are credited

Protocol status: Working We use this protocol and it's working

Created: May 24, 2019

Last Modified: May 24, 2019

PROTOCOL integer ID: 23661

\section{ADDITIONAL INFORMATION}

As of yet we have been unable to demonstrate the actual uptake of plasmid DNA. We have tried using rhodamine labelled plasmids to demonstrate this but the results were inconclusive due to issues with cellular autofluorescence.

We have also tried this method with a variety of expression plasmids encoding different promoters. For example, we tried the MOE promoter from Perkinsus marinus (a closely related species) and the generic eukaryotic CMV promoter. However no GFP fluorescence was detected in these samples.

We have also tried transforming in vitro synthesized GFP encoding mRNA using this protocol. As of yet, no GFP production has been detected, but this may reflect noncannonical translational systems in dinoflagellates as the same mRNA could be translated in starfish embryos.

Although the development of expression systems in dinoflagellates remains a challenge, our results suggest that $O$. marina may be amenable to genetic transformation.

\section{Background information}

1 BEFORE STARTING: Read the abstract for more information and expected outcomes (ex. efficiency, autofluorescence, etc...).

\section{Culturing and cell collection}

Cultures were fed heat-killed E. coliand grown on a 16h/8h light/dark cycle at 20 degrees, cultures were grown in $\mathrm{f} / 2$ media.

The 0 . marina strain we are using is CCMP604.

Cultures were grown to a minimum density of 20,000 cells $/ \mathrm{mL}$

3 Perform cell counts and spin down $1,000,000$ cells per sample in a $50 \mathrm{~mL}$ falcon tube at $3000 \times \mathrm{xg}$ for 10 minutes. 


\section{Resuspend cells in electroporation buffer}

4 Resuspend the O. marina pellet in 100 uL Biorad Gene Pulser Electroporation buffer.

Prior to resuspension we add FITC-dextran (Sigma FD70S) to $2 \mathrm{mg} / \mathrm{mL}$ in the electroporation buffer.

\section{Electroporate the cells}

5 Transfer the resuspended cells to a $0.2 \mathrm{~cm}$ cuvette.

Electroporate using a Biorad Gene Pulser Xcell using the following conditions:

Square wave pulse - $100 \mathrm{~V}, 3 \times 5 \mathrm{~ms}$ pulses, $0.1 \mathrm{~ms}$ pause.

or for lower voltage conditions:

Square wave pulse $-75 \mathrm{~V}, 5 \times 5 \mathrm{~ms}$ pulses, $0.1 \mathrm{~ms}$ pause.

We tried using the exponential protocol with short high voltage pulses ( $1000 \mathrm{~V}, 10 \mathrm{uF}$ ) and long low voltage pulses $(100 \mathrm{~V}, 1000 \mathrm{uF})$ but in all instances the exponential protocol resulted in cell lysis.

We also tried raising the voltage with the square wave protocol ( $200 \mathrm{~V}, 3 \times 5 \mathrm{~ms}, 0.1 \mathrm{~ms}$ pause) but this also resulted in lysis.

After electroporation, add $1 \mathrm{~mL}$ of $\mathrm{f} / 2$ media to the cuvette and transfer the cells to a microcentrifuge tube.

\section{Wash the cells and allow them to recover}

6 After electroporation, spin down the cells for 3 minutes at $7000 \mathrm{xg}$ and wash once with $1 \mathrm{~mL} f / 2$ media.

We allow the cells to recover in 24-well plates for 24 hours before observing.

If you want to avoid photobleaching (ie. for FITC-dextran), you can allow the cells to recover in the dark.

A video demonstrating the results can be seen here: https://www.youtube.com/watch?v=8eHpX- 
GGWWO (sorry for the low quality, the cells also seemed to be slightly squished beneath the slide) 